\title{
Pengujian Berbagai Tipe Tanam Jajar Legowo terhadap Hasil Padi Sawah
}

\author{
The Trial on Different Row Planting Types of "Jajar Legowo" to Yield \\ of Wetland Paddy
}

\author{
Dia Novita Sari ${ }^{1}$, Sumardi $^{2 *}$, EkoSuprijono ${ }^{2}$ \\ ${ }^{1}$ Alumni Program Studi Agroekoteknologi, Fakultas Pertanian, \\ Universitas Bengkulu \\ 2 Program Studi Agroekoteknologi, Fakultas Pertanian, Universitas Bengkulu \\ *:sumardi_unib@yahoo.com
}

\begin{abstract}
Planting wetland paddy by setting row space could be a method to increase rice production. Legowo system is row planting method where we are able to apply different row types on paddy field. The objective of this research was to identify the best row planting type of 'Jajar Legowo' on growth and yield of wetland paddy. Six row plantings, including 2:1 type (means 2 rows are splited by wide spacel legowo), 3:1 type, 4:1 type, 5:1 type, 6:1 type, and 7:1 typ, were tested in a Randomized Complete Block Design with 3 replications Results of the experiment revealed that the highest growth and yield as showed by total number of tillers (28), number of productive tillers (25), dry-mill rice (66.16 g per plant), and yield difference of dry-mill rice (50.43\% per plot) was found at row planting type 2:1. Therefore, row planting type 2:1 can be selected as the best row.
\end{abstract}

Key words: wetland paddy, row type planting, Jajar Legowo

\begin{abstract}
ABSTRAK
Salah satu usaha yang dapat dilakukan untuk meningkatkan produksi padi adalah dengan penataan jarak tanam. Sistem legowo merupakan salah satu penataan terhadap jarak tanam yang didalamnya banyak terdapat tipe tanam jajar legowo. Penelitian ini bertujuan untuk mendapatkan tipe tanam jajar legowo yang terbaik bagi pertumbuhan dan hasil padi sawah. Penelitian disusun dengan rancangan acak kelompok lengkap (RAKL) dengan satu faktor yaitu tipe tanam jajar legowo, setiap satuan percobaan di ulang tiga kali. Tipe tanam jajar legowo meliputi tipe 2:1 (dua baris tanaman diselingi satu legowo), tipe 3:1 (tiga baris tanaman diselingi satu legowo), tipe 4:1 (empat baris tanaman diselingi satu legowo), tipe 5:1 (lima baris tanaman diselingi satu legowo), tipe 6:1 (enam baris tanaman diselingi satu legowo) dan tipe 7:1 (tujuh baris tanaman diselingi satu legowo). Hasil penelitian menunjukkan bahwa tipe tanam jajar legowo 2:1 adalah terbaik bagi pertumbuhan dan hasil padi sawah yang ditunjukkan dengan jumlah anakan total sebesar 28,48 batang, jumlah anakan produktif sebesar 25 batang dan bobot gabah kering giling (GKG) sebesar $66.16 \mathrm{~g}$ per rumpun serta selisih hasil GKG per petak $50.43 \%$.
\end{abstract}

Kata kunci : Padi sawah, tipe tanam jajar legowo 


\section{PENDAHULUAN}

Seiring bertambahnya jumlah penduduk berdampak pada tuntutan peningkatan kebutuhan pangan khususnya beras. Produksi padi di Indonesia pada tahun 2011 mengalami penurunan sebesar $1.07 \%$ menjadi 65.756 .904 ton dari 66.469.394 ton tahun 2010 (Badan Pusat Statistik, 2011). Catatan Badan Pusat Statistik (2010), jumlah penduduk Indonesia dari tahun 2000 hingga 2010 meningkat sebesar $1.52 \%$ menjadi 237.641 .326 jiwa. Kenyataan ini dinilai belum mampu membuat Indonesia swasembada beras.

Salah satu upaya yang dapat dilakukan untuk meningkatkan produksi beras adalah melalui intensifikasi. The System of Rice Intensification (SRI) merupakan metode intensifikasi untuk mening-katkan produktivitas tanaman padi sawah. SRI memiliki beberapa keunggulan dibandingkan cara konvensional, antara lain hemat penggunaan benih, hemat air, waktu penyemaian singkat dan ramah lingkungan (Gani et al.,2001; Rohman dan Soekarno, 2006). Bebe-rapa hasil penelitian menunjukan bahwa SRI dapat memberikan hasil padi sawah yang tinggi. Percobaan di daerah Lempuyung, Lombok budidaya padi sawah dengan metode SRI menghasilkan 9 ton per ha gabah kering giling (GKG), di Madagaskar pada tanah kurang subur menghasilkan 8 ton hingga 15 ton per ha GKG (Berkelaar, 2001) dan di Bengkulu menghasilkan 6.76 ton per ha GKG (Sumardi, 2007).

Tanam padi dengan tipe tanam jajar legowo merupakan pengelolaan jarak tanam dan peng-aturan cara tanam, sehingga diperolah ruang tumbuh yang optimal bagi pertumbuhan dan perkembangan tanaman, mencipta-kan lingkungan yang sub optimal bagi organisme penganggu tanaman (OPT) serta memudahkan dalam melakukan perawatan tanaman. Tipe tanam jajar legowo dikembangkan untukmemanfaatkan pengaruh barisan pinggir tanaman padi (border effect) yang lebih banyak (Departemen Pertanian, 2005). Tanaman pinggir tumbuh dan berkembang lebih baik dan hasil per rumpun lebih tinggi dibandingkan dengan tanaman yang di tengah, sehingga semakin banyak tanaman pinggir border effect di petakan sawah menghasilkan gabah lebih banyak. Menurut Pahrudin et al. (2004), padi yang ditanam secara beraturan dalam bentuk tegel, hasil tanaman per rumpun pada bagian luar lebih tinggi 1.5 hingga 2 kali dibanding hasil per rumpun tanaman yang berada di bagian dalam. Tipe tanam jajar legowo yang digunakan dalam penelitian adalah tipe tanam jajar legowo tanpa adanya penambahan tanaman di antara jarak tanam pada tanaman pinggir, sehingga seluruh tanaman mendapatkan ruang tumbuh yang sama. Dalam upaya meningkatkan hasil padi sawah dilakukan pengujian modifikasi berbagai tipe tanam jajar legowo. Pengujian bertujuan untuk mendapatkan tipe tanam jajar legowo yang terbaik bagi partumbuhan dan hasil padi sawah.

\section{METODEPENELITIAN}

Penelitian dilaksanakan pada bulan Januari 2012 hingga April 2012 di Balai Benih Pembantu (BBP) Dinas Pertanian Kota Bengkulu berlokasi di Kelurahan Semarang, Kecamatan Sungai Serut, Kota Bengkulu.

Penelitian menggunakan rancangan acak kelompok lengkap (RAKL) dengan 1 faktor yaitu tipe tanam jajar legowo, yang meliputi: L1 $(2: 1)=$ dua baris tanaman diselingi satu legowo, L2 (3:1) = tiga baris tanaman diselingi satu legowo, L3 (4:1) = empat baris tanaman diselingi satu legowo, L4 $(5: 1)=$ lima baris tanaman diselingi satu legowo, L5 (6:1) = enam baris tanaman diselingi satu legowo dan L6 (7:1) = tujuh baris tanaman diselingi 
satu legowo sehingga diperoleh 6 tipe tanam jajar legowo. Setiap perlakuan diulang sebanyak 3 ulangan. Untuk mengetahui hasil pengaruh keenam tipe tanam jajar legowo, maka dibandingkan dengan cara tanam petani (jarak tanam $20 \mathrm{~cm}$ x $20 \mathrm{~cm}$ dan lebar legowo $40 \mathrm{~cm})$.

Lahan yang digunakan pada penelitian adalah lahan sawah beririgasi teknis. Petak percobaan dibuat dengan ukuran $5 \mathrm{~m} \times 2 \mathrm{~m}$, bagian pinggir petakan dibuat parit sedalam lebih kurang $10 \mathrm{~cm}$. Jumlah petak percobaan dalam penelitian ini sebanyak 18 petak percobaan dengan jarak antar petak $50 \mathrm{~cm}$ dan jarak antar ulangan $100 \mathrm{~cm}$. Tata cara pembuatan legowo pada penelitian adalah sebagai berikut : pada tipe tanam jajar legowo 2:1 setiap dua baris tanaman diselinggi dengan lorong $40 \mathrm{~cm}$ dengan jarak tanam dalam barisan $25 \mathrm{~cm}$ x $25 \mathrm{~cm}$. Pada tipe tanam jajar legowo 3:1 setiap tiga baris tanaman diselinggi dengan lorong $40 \mathrm{~cm}$ dan jarak tanam dalam barisan $25 \times 25 \mathrm{~cm}$. Tipe tanam jajar legowo 4:1 setiap empat baris tanaman diselinggi lorong $40 \mathrm{~cm}$. Begitu juga untuk tipe lainnya yang ditanam sesuai jumlah baris dan diselingi lorong $40 \mathrm{~cm}$.

Benih yang digunakan adalah varietas Inpari 13. Sebelum ditanam, benih direndam dalam air selama 24 jam dan benih yang terapung dibuang. Kemudian, benih dikecam-bahkan dengan cara ditiriskan dan diletakan dalam wadah yang beraerasi baik selama 48 jam. Setelah berkecambah (keluar plumule dan radicle), kecambah ditebarkan di persemaian. Penyemaian dilakukan secara basah di lahan sawah, dengan terlebih dahulu membuat lahan semai yang berukuran $2 \mathrm{~m} \mathrm{x}$ $1 \mathrm{~m}$.

Penanaman dilakukan pada saat semaian berumur 12 hari setelah sebar benih (HSSB). Bibit diambil dengan cara mengangkat bagian bawah tanahnya untuk menghindari putusnya akar. Setelah bibit diambil dari media persemaian, bibit langsung ditanam pada petak percobaan. Penanaman 1 bibit per lubang tanam dengan kedalaman $1 \mathrm{~cm}$ hingga $1.5 \mathrm{~cm}$. Penyulaman dilakukan dengan cara menanam bibit kembali ke bekas tanaman yang mati pada setiap petak percobaan dengan bibit yang umurnya sama dengan bibit yang ditanam sebelumnya.

Pemeliharaan yang dilakukan meliputi pemupukan, pengairan, pengelolaan gulma dan pengelolaan organisme penganggu tanaman. Pemberian pupuk Urea dengan dosis $200 \mathrm{~kg}$ per ha (200 g per petak) diberikan dua kali yaitu pada saat tanaman berumur satu minggu setelah tanam (MST) dan enam MST ketika tanaman padi memasuki fase primordial, masing-masing setengah dosis. Sedangkan pemberian pupuk SP-36 dengan dosis $150 \mathrm{~kg}$ per ha (150 g per petak) dan pupuk $\mathrm{KCl}$ dengan dosis 100 $\mathrm{kg}$ per ha (100 g per petak) diberikan pada saat tanaman berumur satu MST. Pemberian pupuk diberikan dengan cara menaburkan secara merata pada setiap petak percobaan pada kondisi tanah lembab. Pengelolaan air diupayakan agar tanaman tidak kekurangan air, namun air tidak sampai menggenang lama dalam petakan sawah. Lahan sawah dikeringkan sejak tanam sampai tanaman berumur 10 hari setelah tanam (HST). Lahan penelitian diupayakan lembab, dengan cara memompa air dari saluran pembuangan satu kali seminggu. Pengendalian organisme penganggu tanaman (OPT) seperti hama, penyakit dan gulma dilakukan sesuai dengan kondisi. Pengendalian hama sundep (Scrirpophaga innotata) dilakukan dengan menyemprotkan insektisida fibronil $50 \mathrm{~g}$ per L dengan dosis $1 \mathrm{~mL}$ per L air. Penyakit busuk leher malai (Pylicularia grisea) yang disebabkan oleh jamur dikendalikan dengan difenokonazol $250 \mathrm{~g}$ per L dengan dosis 1 


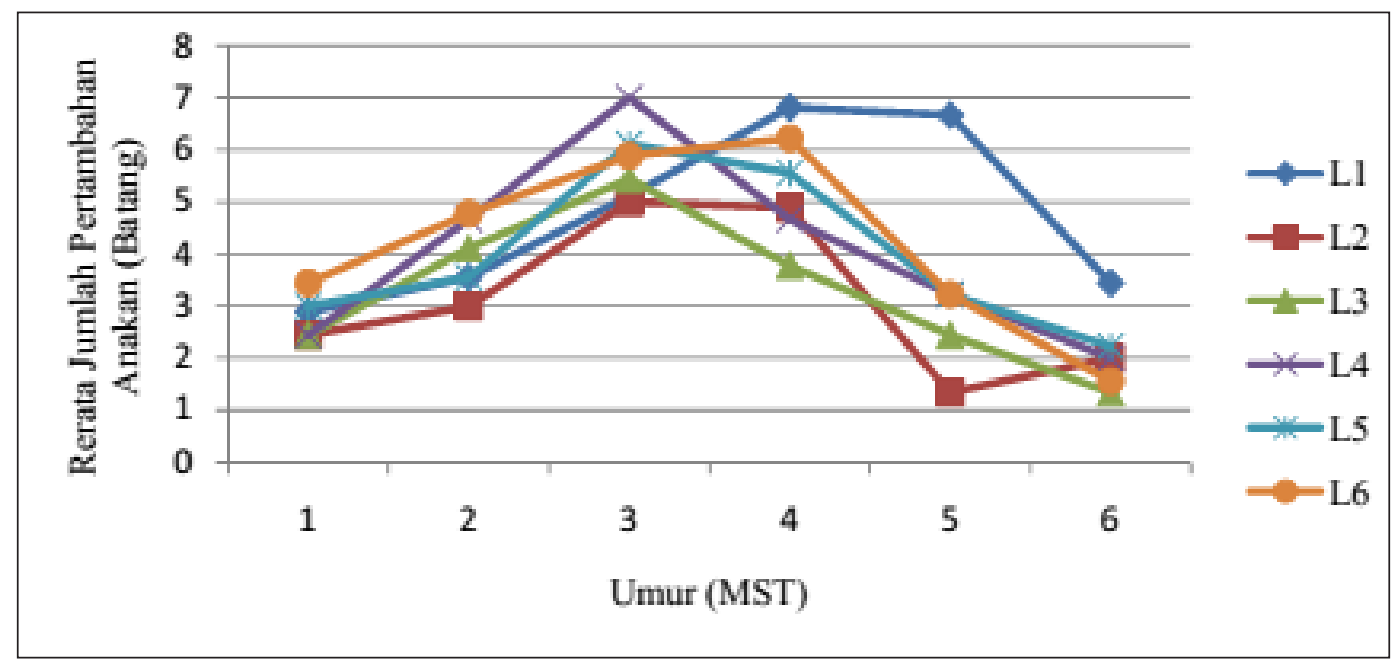

Grafik 1. Rerata jumlah pertambahan anakan (batang) dari umur 1 hingga 6 SMT pada berbagai tipe tanam jajar legowo

$\mathrm{mL}$ per L air. Pengendalian gulma dilakukan secara kimia karena gulma berkembang cukup cepat dan rapat, menggunakan herbisida dimetilamina $865 \mathrm{~g}$ per L dengan dosis 1.5 $\mathrm{mL}$ per L air. Satu minggu setelah aplikasi herbisida, hanya gulma daun lebar yang mati, sedangkan gulma daun sempit tetap hidup dan berkembang sehingga dikendalikan dengan cara mencabut gulma secara langsung dengan tangan.

Panen dilakukan pada saat tanaman berumur 93 HST dengan menunjukkan kriteria sebagai berikut :

(1) Lebih dari delapan puluh persen total populasi bulir pada malai padi sudah berwarna kuning keemasan.

(2) Daun bendera telah menguning dan malai padi merunduk karena menopang bulirbulir yang bernas.

(3) Butir gabah keras bila ditekan dengan jari tangan dan apabila ditekan dengan kuku tidak meninggalkan bekas. Apabila dikupas, tampak isi butir gabah berwarna putih dan keras bila digigit. Kadar air gabah sekitar 18\% hingga $20 \%$.

\section{HASIL DAN PEMBAHASAN}

\section{Jumlah Pertambahan Anakan (batang)}

Perbedaan tipe tanam jajar legowo yang digunakan yaitu tipe $2: 1,3: 1,4: 1,5: 1,6: 1$, dan $7: 1$ tidak memberikan pengaruh yang nyata terhadap jumlah pertambahan anakan untuk semua periode pengamatan kecuali pada umur 5 MST. Rerata jumlah pertambahan anakan disajikan pada Grafik 1. Berdasarkan Grafik 1 di atas, diketahui bahwa tipe tanam jajar legowo 2:1 pada umur 5 MST memberikan jumlah pertambahan anakan tertinggi dibanding tipe tanam jajar legowo lain. Pada awal pertumbuhan yakni umur 1 MST hingga 4MST jumlah pertambahan anakan cenderung sama, selanjutnya jumlah pertambahan anakan mengalami penurunan hingga umur 6 MST. Jumlah pertambahan anakan yang menurun karena tanaman telah memasuki fase generatif, sehingga pertumbuhan vegetatif (pembentukan anakan) mulai menurun. Hasil fotosintesis berupa bahan kering sebagian besar ditranslokasikan ke organ generatif tanaman. Selain itu juga terjadi persaingan di dalam rumpun tanaman itu sendiri sehingga 


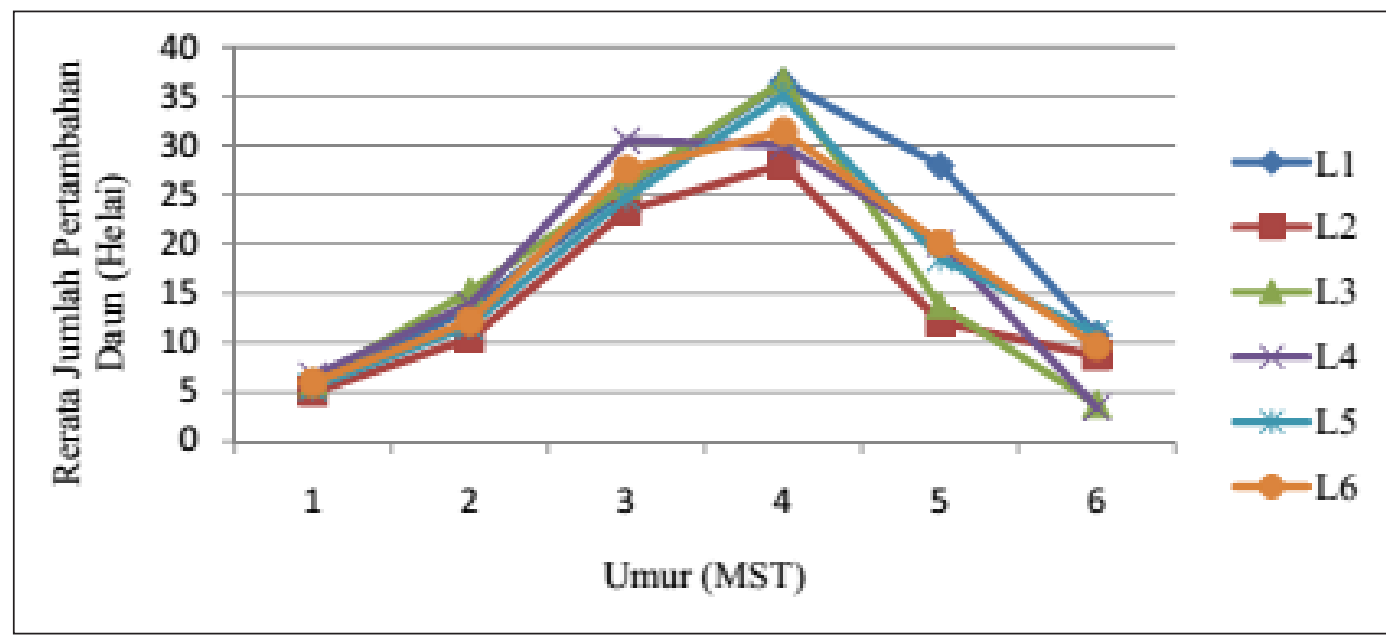

Grafik 2. Rerata jumlah pertambahan daun (helai) dari umur 1 hingga 6 MST pada berbagai tiipe tanam jajar legowo

anakan yang kalah bersaing menjadi tidak berkembang atau mati. Sitompul dan Guritno (1995) menyatakan bahwa pola pertumbuhan tanaman semusim pada fase vegetatif terus meningkat hingga memasuki fase generatif, selanjutnya akan mengalami penurunan hingga berhenti pada fase pemasakan biji hingga panen.

Hasil penelitian ini sejalan dengan Muliasari dan Sugiyanta (2009) yang menyatakan bahwa, pertambahan jumlah anakan akan berlangsung secara terusmenerus sampai tercapai jumlah anakan produktif, kemudian beberapa anakan mati dan jumlahnya akan menurun sampai tercapai pada kondisi jumlah yang tetap.

\section{Jumlah Pertambahan Daun (helai)}

Perbedaan tipe tanam jajar legowo yang digunakan dari tipe 2:1 hingga 7:1 tidak memberikan pengaruh yang nyata terhadap jumlah pertambahan daun hingga untuk umur 6 MST. Jumlah pertambahan daun dari umur 1 hingga 6 MST cenderung sama untuk semua tipe tanam jajar legowo (Grafik2). Hal ini menunjukkan bahwa adanya perbedaan lingku-ngan tumbuh tidak mempengaruhi pembentukan daun sehingga jumlah pertambahan daun yang dihasilkan cenderung sama. Jumlah pertambahan daun cenderung meningkat hingga umur 4 MST. Peningkatan jumlah daun seiring dengan meningkatnya umur tanaman, selanjutnya jumlah pertambahan daun mengalami penurunan hingga umur 6 MST. Penurunan jumlah daun terjadi diakibatkan sebagian daun tanaman sudah tua dan gugur karena tidak dapat melakukan proses fotosintesis. Di samping itu, penurunan jumlah daun disebabkan tanaman sudah memasuki fase generatif sehingga fase vegetatif (pembentukan daun) terhenti karena hasil fotosintesis berupa bahan kering lebih besar ditranslokasikan ke pembentukan malai.

\section{Jumlah Anakan Total (batang), Jumlah Daun Total (helai) dan Tinggi Tanaman (cm)}

Perbedaan tipe tanam jajar legowo yang digunakan dari tipe 2:1 hingga 7:1 memberikan pengaruh yang nyata terhadap jumlah anakan total, tetapi tidak memberikan pengaruh yang nyata terhadap jumlah daun total dan tinggi tanaman. Rerata jumlah 
Tabel 1. Rerata jumlah anakan total (JAT), jumlah daun total (JDT) dan tinggi tanaman (TT) pada berbagai tipe tanam jajar legowo

\begin{tabular}{lccc}
\hline Tipe tanam jajar & \multicolumn{3}{c}{ Rerata } \\
\cline { 2 - 4 } legowo & JAT (batang) & JDT (helai) & TT (cm) \\
\hline Tipe $(2: 1)$ & $28.48^{\mathrm{a}}$ & 119.99 & 98.71 \\
Tipe $(3: 1)$ & $18.66^{\mathrm{c}}$ & 87.77 & 101.76 \\
Tipe $(4: 1)$ & $19.55^{\mathrm{bc}}$ & 101.33 & 104.44 \\
Tipe $(5: 1)$ & $23.99^{\mathrm{abc}}$ & 104.66 & 106.43 \\
Tipe $(6: 1)$ & $23.66^{\mathrm{abc}}$ & 106.66 & 105.45 \\
Tipe $(7: 1)$ & $25.11^{\mathrm{ab}}$ & 106.99 & 104.34 \\
\hline
\end{tabular}

Keterangan: Angka-angka pada kolom yang sama diikuti huruf kecil yang sama, berbeda tidak nyata pada LSD taraf $5 \%$.

anakan total, jumlah daun total dan tinggi tanaman disajikan pada Tabel 1.

Berdasarkan Tabel 1 di atas, ditunjukkan bahwa jumlah anakan total tertinggi dicapai oleh tipe 2:1. Tipe 2:1 dapat membentuk anakan sebesar 28.48 batang sedangkan tipe tanam jajar legowo lainnya hanya berkisar antara 18.66 hingga 25.11 batang. Penggunaan tipe tanam jajar legowo yang berbeda dan jarak tanam yang cukup lebar serta umur bibit tanam yang masih muda sangat menentukan jumlah anakan yang terbentuk. Tipe tanam jajar legowo 2:1 membentuk jumlah anakan total paling tinggi karena merupakan dampak dari banyaknya lorong-lorong yang cukup lebar di antara barisan tanaman. Hasil ini sejalan dengan Yetti dan Ardian (2010) yang mengemukakan bahwa semakin lebar jarak tanam yang digunakan, maka anakan yang dihasilkan lebih banyak, hal ini disebabkan persaingan mendapatkan sinar matahari dan unsur hara kecil. Menurut Gardner et al. (1985), jumlah anakan akan terbentuk maksimal apabila tanaman mempunyai sifat genetik yang baik ditambah dengan keadaan lingkungan yang menguntungkan atau sesuai dengan pertumbuhan dan perkembangan tanaman.
Jumlah daun total yang terbentuk untuk semua tipe tanam jajar legowo memberikan hasil yang cenderung sama (Tabel 1). Terbentuknya jumlah daun total merupakan akumulasi dari jumlah pertambahan daun. Dengan demikian maka jumlah pertambahan daun secara langsung mempengaruhi jumlah daun total yang terbentuk. Tidak adanya perbedaan jumlah daun total yang terbentuk mengindikasikan bahwa selama proses pertumbuhan vegetatif, tanaman tidak mengalami persaingan dalam hal menangkap energi dari cahaya matahari untuk melakukan proses fotosintesis. Keadaan demikian terjadi merupakan dampak dari penggunaan jarak tanam yang cukup lebar serta adanya jajar legowo di antara barisan tanaman padi sehingga membuat kondisi lingkungan tumbuh tanaman optimal. Jumlah daun total yang terbentuk sepenuhnya tidak dipengaruhi oleh lingkungan tumbuhnya melainkan oleh sifat genotipe tanaman itu sendiri. Hasil penelitian diperkuat dengan pendapat Gardner et al. (1985) yang mengemukakan bahwa genotipe suatu spesies dan lingkungan tumbuh akan sangat mempengaruhi jumlah dan ukuran daun yang terbentuk.

Perbedaan tipe tanam jajar legowo tidak mempengaruhi tinggi tanaman (Tabel 1). 
Tabel 2. Rerata jumlah anakan produktif (JAP), panjang malai (PM), jumlah bulir per malai (JBPM), persentase bulir bernas (PBB) dan berat 100 biji (BB) pada berbagai tipe tanam jajar legowo.

\begin{tabular}{lccccc}
\hline \multirow{2}{*}{$\begin{array}{c}\text { Tipe jajar } \\
\text { legowo }\end{array}$} & $\begin{array}{c}\text { JAP } \\
\text { (batang) }\end{array}$ & $\begin{array}{c}\text { PM } \\
\mathbf{( c m )}\end{array}$ & $\begin{array}{c}\text { JBPM } \\
\text { (butir) }\end{array}$ & $\begin{array}{c}\text { PBB } \\
\mathbf{( \% )}\end{array}$ & $\begin{array}{c}\text { BB } \\
(\mathbf{g})\end{array}$ \\
\hline Tipe $(2: 1)$ & $25.00^{\mathrm{a}}$ & 26.66 & 158.50 & 86.82 & $2.60^{\mathrm{b}}$ \\
Tipe $(3: 1)$ & $17.46^{\mathrm{b}}$ & 26.82 & 154.30 & 77.77 & $2.67^{\mathrm{b}}$ \\
Tipe $(4: 1)$ & $18.40^{\mathrm{b}}$ & 26.30 & 149.53 & 86.58 & $2.82^{\mathrm{a}}$ \\
Tipe $(5: 1)$ & $18.86^{\mathrm{b}}$ & 26.93 & 172.90 & 77.88 & $2.66^{\mathrm{b}}$ \\
Tipe $(6: 1)$ & $20.56^{\mathrm{b}}$ & 26.77 & 162.40 & 81.09 & $2.70^{\mathrm{ab}}$ \\
Tipe $(7: 1)$ & $20.50^{\mathrm{b}}$ & 26.49 & 159.66 & 81.79 & $2.82^{\mathrm{a}}$ \\
\hline
\end{tabular}

Keterangan: Angka-angka pada kolom yang sama diikuti huruf kecil yang sama, berbeda tidak nyata pada LSD taraf $5 \%$.

Berdasarkan deskripsi tanaman padi varietas Inpari 13 tinggi tanaman hanya $101 \mathrm{~cm}$, sedangkan pada penelitian menunjukkan tinggi tanaman yang mencapai $103.52 \mathrm{~cm}$. Hal ini menunjukkan tinggi tanaman yang dicapai telah optimal dengan tipe tanam jajar legowo.

\section{Jumlah Anakan Produktif (batang), Panjang Malai (cm), Jumlah Bulir per Malai (butir), Persentase Bulir Bernas (\%) dan Berat 100 biji (g)}

Perbedaan tipe tanam jajar legowo yang digunakan dari tipe 2:1 hingga 7:1 memberikan pengaruh yang nyata terhadap jumlah anakan produktif dan berat 100 biji, tetapi tidak memberikan pengaruh yang nyata terhadap panjang malai, jumlah bulir per malai dan persentase bulir bernas. Rerata jumlah anakan produktif disajikan pada Tabel 2. Berdasarkan Tabel 2, bahwa jumlah anakan produktif tertinggi dicapai tipe tanam jajar legowo 2:1 dan tipe tanam jajar legowo lainnya sama. Tipe tanam jajar legowo 2:1 dapat membentuk jumlah anakan produktif sebesar 25.00 batang sedangkan tipe tanam jajar legowo lain hanya berkisar antara17.46 hingga 20.56 batang. Berdasarkan deskripsi varietas Inpari 13, jumlah anakan produktif hanya 17 batang per rumpun. Hal ini menunjukkan bahwa jumlah anakan produktif yang terbentuk telah optimal untuk semua tipe tanam jajar legowo. Jumlah anakan produktif yang tinggi terbentuk pada tipe tanam jajar legowo 2:1 karena langsung dipengaruhi oleh jumlah pertambahan anakan dan jumlah anakan total yang telah terbentuk sebelumnya. Sejalan dengan pendapat Yetti dan Ardian (2010) mengatakan bahwa jumlah anakan produktif yang kemudian menghasilkan gabah dipengaruhi oleh jumlah anakan total.

Panjang malai yang dihasilkan semua tipe tanam jajar legowo cenderung sama (Tabel 2). Adanya perbedaan tipe tanam jajar legowo yang digunakan ternyata tidak menimbulkan perbedaan pada panjang malai yang dihasilkan. Panjang malai merupakan salah satu komponen penting dalam menentukan hasil karena semakin panjang malai maka jumlah bulir per malai akan semakin seningkat. Panjang malai merupakan suatu sifat yang diturunkan secara genetik, 
jika kondisi lingkungan tempat tumbuhnya sama maka akan memiliki panjang malai yang relatif seragam untuk varietas yang sama.

Berdasarkan Tabel 2 di atas, ditunjukkan bahwa sama halnya dengan panjang malai, jumlah bulir per malai juga merupakan sifatyang diturunkan secara genetik. Dengan demikian maka jumlah bulir per malai untuk semua tipe tanam jajar legowo cenderung sama. Jumlah bulir per malai telah terbentuk sejak tanaman memasuki fase primordia. Adanya perbedaan kondisi lingkungan yang tidak ekstrim hingga tanaman memasuki fase primordia relatif tidak akan mempengaruhi jumlah bulir yang sudah terbentuk. Hasil penelitian ini sejalan dengan penelitian Sumardi (2007) bahwa panjang malai dan jumlah bulir per malai merupakan satu kesatuan sifat yang ditentukan oleh faktor genetik dari suatu varietas. Panjang malai dan jumlah bulir per malai akan cenderung sama jika kondisi lingkungan tumbuh relatif seragam.

Persentase bulir bernas untuk semua tipe tanam jajar legowo cenderung sama (Tabel 2). Ini berbeda dengan penelitian Sumardi (2010) bahwa persentase bulir bernas akan cenderung meningkat jika populasi tanaman semakin rendah. Dalam penelitian, tipe tanam jajar legowo 2:1 memiliki populasi tanaman paling rendah di antara tipe tanam jajar legowo lain dengan jarak tanam yang cukup lebar masih belum mampu memberikan pengaruh terhadap persentase bulir bernas. Hal ini tidak sesuai dengan pendapat Yetti dan Ardian (2010) bahwa persentase gabah bernas akan semakin meningkat jika jarak tanam yang digunakan semakin lebar. Bernas atau tidaknya gabah dipengaruhi oleh hasil fotosintat yang berasal dari dua sumber, yaitu hasil-hasil asimilasi sebelum pembuahan yang disimpan dalam jaringan batang dan daun yang kemudian diubah menjadi zat-zat gula dan diangkut ke biji dan hasil asimilasi yang dibuat selama fase pemasakan.

Bobot 100 biji tertinggi diperoleh tipe tanam jajar legowo 4:1 dan tipe tanam jajar legowo 7:1 serta diikuti tipe tanam jajar legowo 6:1 (Tabel 2). Secara berurutan besarnya bobot 100 biji sebesar $2.82 \%$ dan $2.70 \%$, sedangkan tipe tanam jajar legowo lain hanya berkisar antara $2.60 \%$ hingga 2.66 $\%$. Ini berarti bahwa penggunaan tipe tanam jajar legowo yang berbeda memberikan pengaruh yaitu kondisi lingkungan tumbuh yang berbeda sehingga diperoleh bobot 100 biji yang beragam. Bobot 100 biji tertinggi pada tipe 4:1 dan tipe 7:1 karena hasil dari proses fotosintesis berupa bahan kering langsung ditranslokasikan menuju malai untuk melakukan pengisian terhadap bulir, sehingga dapat memperoleh bobot 100 biji yang tinggi. Hal ini terjadi karena anakan telah terbentuk secara maksimal sebelum tanaman memasuki fase generatif. Tentunya hal ini berbeda dengan tipe tanam jajar legowo 2:1 yang memperoleh bobot 100 biji terendah. Keadaan ini terjadi karena hasil dari fotosintesis sebagian besar tidak ditranslokasikan menuju malai, melainkan digunakan untuk pembentukan anakan karena pada fase generatif tipe tanam jajar legowo 2:1 tetap membentuk anakan. Hasil penelitian menunjukkan bahwa faktor lingkungan mempengaruhi bobot 100 biji. Kenyataan ini sependapat dengan Sumardi (2007) yang menyatakan bahwa, jika terjadi variasi berat 1000 biji maka ada indikasi bahwa faktor lingkungan yang berperan. Perbedaan berat 1000 biji dari varietas yang sama menggambarkan terjadi variasi jumlah dan ukuran sel endosperm dalam biji.

\section{Bobot GKG per Rumpun (g) dan Hasil GKG per Petak}

Perbedaan tipe tanam jajar legowo yang digunakan dari tipe 2:1 hingga $7: 1$ 
Tabel 3. Rerata bobot GKG per rumpun (GKGR), hasil GKG per petak (GKGP) dan selisih hasil GKG per petak pada berbagai tipe tanam jajar legowo.

\begin{tabular}{|c|c|c|c|}
\hline \multirow[b]{2}{*}{ Tipe jajar legowo } & \multicolumn{3}{|c|}{ Rerata } \\
\hline & GKGR (g) & GKGP (g) & $\begin{array}{c}\text { Selisih hasil per petak } \\
(\%)\end{array}$ \\
\hline Tipe $(2: 1)$ & $66.16^{a}$ & 6510.73 & 50.43 \\
\hline Tipe $(3: 1)$ & $41.83 \mathrm{~b}$ & 5272.16 & 21.80 \\
\hline Tipe $(4: 1)$ & 50.52 b & 5864.83 & 35.51 \\
\hline Tipe $(5: 1)$ & $47.41 \quad \mathrm{~b}$ & 6242.93 & 44.24 \\
\hline Tipe $(6: 1)$ & $47.49 \mathrm{~b}$ & 5651.43 & 30.58 \\
\hline Tipe $(7: 1)$ & 52.87 ab & 5656.83 & 30.70 \\
\hline Cara tanam petani & & 4327.93 & - \\
\hline
\end{tabular}

memberikan pengaruh yang nyata terhadap bobot GKG per rumpun, tetapi tidak memberikan pengaruh yang nyata terhadap hasil GKG per petak. Rerata bobot GKG per rumpun dan hasil GKG per petak disajikan pada Tabel 3. Berdasarkan Tabel 3, ditunjukkan bahwa tipe tanam jajar legowo 2:1 memperoleh bobot GKG per rumpun tertinggi dibanding tipe tanam jajar legowo lain. GKG pada tipe tanam jajar legowo 2:1 mencapai bobot sebesar $66.16 \mathrm{~g}$ dan diikuti tipe tanam jajar legowo 7:1 sebesar $52.87 \mathrm{~g}$ sedangkan tipe tanam jajar legowo lainnya hanya berkisar antara 41.83 hingga $50.52 \mathrm{~g}$. Fenomena ini terjadi karena tipe tanam jajar legowo 2:1 lebih banyak menyediakan ruang kosong bagi tanaman sehingga dapat memberikan sirkulasi udara, pemasukan cahaya dan juga aliran air serta penyebaran unsur hara yang lebih merata sehingga memberi efek pertumbuhan dan hasil tanaman yang lebih baik. Tipe tanam jajar legowo 7:1 didukung oleh jumlah populasi tanaman yang lebih tinggi. Bobot per rumpun $\mathrm{GKG}$ pada tipe 2:1 yang tinggi tentunya berkaitan dengan tingginya jumlah pertambahan anakan (Grafik 1), jumlah anakan total (Tabel 1) dan jumlah anakan produktif (Tabel 2) yang terbentuk. Komponen tersebut yang membuat tipe tanam jajar legowo 2:1 memperoleh hasil gabah per rumpun lebih tinggi walaupun populasi tanaman rendah. Hal ini sejalan dengan penelitian Sumardi (2010) menyatakan bahwa semakin rendah populasi tanaman maka hasil gabah per rumpun akan cenderung meningkat.

Hasil GKG per petak untuk semua tipe tanam jajar legowo yang digunakan cenderung sama (Tabel 3). Diketahui bahwa cara tanam petani memiliki hasil paling rendah yaitu sebesar $4327.93 \mathrm{~g}$ dibanding dengan berbagai tipe tanam jajar legowo yang digunakan. Selisih hasil GKG per petak untuk masingmasing tipe tanam jajar legowo cenderung lebih tinggi bila dibandingkan dengan cara tanam petani. Selisih hasil tertinggi dicapai tipe tanaman jajar legowo 2:1 sebesar $50.43 \%$. Hasil penelitian ini berbeda dengan penelitian Azwir (2008) menghasilkan GKG panen sebesar 6.39 ton per ha, sedangkan dalam penelitian ini mampu menghasilkan GKG sebesar 6.51 ton per ha untuk perlakuan tipe tanam 


\section{KESIMPULAN}

Pertumbuhan dan hasil padi sawah terbaik dicapai oleh tipe tanam jajar legowo 2:1, yang ditunjukkan pada jumlah anakan total yang mencapai 28.48 batang, jumlah anakan produktif 25 batang dan GKG per rumpun $66.16 \mathrm{~g}$.

\section{DAFTAR PUSTAKA}

Azwir. 2008. Sistem tanam legowo dan pemberian P-Stater pada padi sawah dataran tinggi. Akta Agrosia XI(2): 102 - 107.

Badan Pusat Statistik. 2010. Jumlah Penduduk Indonesia. Badan Pusat Statistik, Jakarta.

Badan Pusat Statistik. 2011. Produksi Padi Nasional. Badan Pusat Statistik, Jakarta.

Berkelaar, D. 2001. Sistem intensifikasi padi (the system of rice intensification-SRI) : Sedikit dapat memberi lebih banyak. 7 hal terjemahan. ECHO, Inc. 17391 DurranceRd. NorthFt. MyersFL. 33917 USA.

Departemen Pertanian. 2005. Budidaya Mina Padi Azolla Dengan Tanam Jajar Legowo. Departemen Pertanian, Jakarta.

Gani, A., T.S. Kadir., A. Jatiharti., I.P. Wardhana and I. Las. 2001. The system of rice intensification in Indonesia. Research Institutefor Rice, Agency for Agricultural Reseach and Development, Bogor.

Gardner, P.F., R.B. Pearce dan R.I. Michell. 1985. Physiology of Crop Plants. The Lowa State University Press. Ames,
Lowa. Diterjemahkan oleh Susilo, H. 2008. Fisiologi Tanaman Budidaya. Universitas Indonesia Press, Jakarta.

Muliasari, A.A dan Sugiyanta. 2009. Optimalisasi jarak tanam dan umur bibit pada padi sawah (Oryza sativa L.). Makalah seminar Departemen Agronomi dan Hortikultura IPB, Bogor.

Pahrudin, A., Maripul dan P.R. Dida. 2004. Cara tanam padi sistem legowo mendukung usaha tani di Desa Bojong Cikembar Sukabumi. Buletin Tehnik Pertanian IX (1) : 10- 12.

Rohman, D., dan I, Soekarno. 2006. SRI suatu altenatif peningkatan produktivitas lahan sawah (padi) yang berwawasan lingkungan. Pelantikan Pengurus KNIICID Komda Bandung. Pertemuan Dinas PSDA Bandung. 10 Agustus 2006.

Sitompul, M dan B. Guritno. 1995. Analisis Pertumbuhan Tanaman. Gadjah Mada University Press, Yogyakarta.

Sumardi. 2007. Peningkatan produktivitas padi sawah melalui aplikasi bahan organik pada metode SRI ( The Sistemof Rice Intensification). Disertasi. Program PascaSarjana. Universitas Andalas, Padang. (tidak dipublikasikan).

Sumardi. 2010. Produktivitas padi sawah pada kepadatan berbeda. Ilmu-ilmu Pertanian Indonesia XII (1) : 49-54.

Yetti, H dan Ardian. 2010. Pengaruh penggunaan jarak tanam terhadap pertumbuhan dan produksi padi sawah (Oryza sativa L) varietas IR 42 dengan metode SRI (Sistem Of Rice Intensification). Sagu IX(1) : 21 - 27. 